DOI: $10.19195 / 2084-5065.50 .3$

\title{
Artykuł 59a k.k. - sukces czy porażka ustawodawcy
}

\author{
BOGDAN MYRnA \\ ORCID: 0000-0002-0501-0588 \\ Prokuratura Okręgowa we Wrocławiu
}

Ustawa o zmianie ustawy Kodeks postępowania karnego oraz niektórych innych ustaw ${ }^{1}$ (w brzmieniu nadanym przez ustawę $\mathrm{z}$ dnia 20 lutego 2015 roku o zmianie ustawy Kodeks karny oraz niektórych innych ustaw (Dz.U. 2015 poz. 396)) wprowadziła do kodeksu karnego nowy przepis, art. 59a, nakazujący umorzenie postępowania karnego na wniosek pokrzywdzonego. Instytucję tę można zatem nazwać umorzeniem wnioskowym. Przede wszystkim jednak należy ją określić jako umorzenie kompensacyjne albo umorzenie restytucyjne ${ }^{2}$. Do zastosowania tegoż

${ }^{1}$ Ustawa z dnia 27 września 2013 r. o zmianie ustawy Kodeks postępowania karnego oraz niektórych innych ustaw, Dz.U. 2013 poz. 1247. Ściślej mówiąc, art. 59a k.k. został dodany przez art. 12 pkt 1 cyt. ustawy i zaczął obowiązywać od dnia 1 lipca 2015 r.

${ }^{2}$ Zob. na przykład K. Chojniak, Umorzenie restytucyjne — odpowiedź na zjawisko nadmiernej kryminalizacji i penalizacji?, [w:] Granice kryminalizacji i penalizacji, red. S. Pikulski, M. Romańczuk-Grądzka, Olsztyn 2013, s. 609-617; R. Koper, Warunki umorzenia postępowania karnego w trybie art. 59a k.k., „Ius Novum” 2014, nr 3, s. 11-25; A. Lach, Umorzenie postępowania karnego na podstawie art. 59a k.k., „Prokuratura i Prawo" 2015, nr 1-2 , s. 137-148; Z. Sienkiewicz, [w:] Prawo karne materialne. Czesść ogólna i szczególna, red. M. Bojarski, J. Giezek, Z. Sienkiewicz, Warszawa 2015, s. 368-369. 
umorzenia muszą być — zgodnie z treścią art. 59a § 1 k.k. — spełnione kumulatywnie następujące warunki:

- popełnienie przestępstwa (występku) zagrożonego karą nieprzekraczającą 3 lat pozbawienia wolności lub przestępstwa (występku) przeciwko mieniu zagrożonego karą nieprzekraczającą 5 lat pozbawienia wolności, jak również przestępstwa (występku) określonego w art. 157 $\S 1$ k.k.,

- sprawca nie był uprzednio skazany za przestępstwo umyślne z użyciem przemocy,

- sprawca przed rozpoczęciem przewodu sądowego w pierwszej instancji pojednał się z pokrzywdzonym w szczególności w wyniku mediacji i naprawił szkodę lub zadośćuczynił wyrządzonej krzywdzie,

— pokrzywdzony złożył wniosek o przedmiotowe umorzenie.

Umorzenie postępowania karnego na podstawie art. 59a k.k. było zatem możliwe w przypadku wszystkich typów przestępstw, które zostały zagrożone karą lub karami wolnościowymi albo sankcją alternatywną zawierającą zagrożenie karami wolnościowymi lub karą pozbawienia wolności (bez względu na jej górną granicę zagrożenia), albo sankcją prostą przewidującą wyłącznie zagrożenia karą pozbawienia wolności nieprzekraczającą 3 lat, albo też sankcją kumulatywną przewidującą karę pozbawienia wolności nie wyższą niż 3 lata i grzywnę ${ }^{3}$ Ponadto, w myśl przepisu art. 59a k.k., umorzenie kompensacyjne było również możliwe w przypadku wszystkich typów przestępstw przeciwko mieniu (w tym także spoza rozdziału XXXV k.k., albowiem ustawodawca nie wskazał w sposób jednoznaczny, że ma tutaj chodzić wyłącznie o przestępstwa przeciwko mieniu, określone w rozdziale XXXV k.k.), zagrożonych karą nieprzekraczającą 5 lat pozbawienia wolności, a ponadto $\mathrm{w}$ wypadku wprost wskazanego przez ustawodawcę przestępstwa określonego w art. 157 § 1 k.k. Poprzez użycie sformułowania ,zagrożonego" ustawodawca przesądził, że do zastosowania tej instytucji

3 V. Konarska-Wrzosek, [w:] Kodeks karny. Komentarz, red. R.A. Stefański, Warszawa 2015, s. 396. 
(umorzenia kompensacyjnego) decydujące znaczenie ma wysokość kary, jaka jest przewidziana w przepisie części szczególnej, bez uwzględnienia okoliczności prowadzących do jej nadzwyczajnego obostrzenia bądź złagodzenia ${ }^{4}$. Oczywiście nie wyklucza to - jak słusznie zauważa A. Pilch - umorzenia postępowania w trybie art. 59a k.k. w przypadku realizacji przez sprawcę znamion przestępstwa zagrożonego karą łagodniejszego rodzaju, to jest karą grzywny lub karą ograniczenia wolności $^{5}$. Z dobrodziejstwa art. 59a k.k. mógł skorzystać sprawca, który nie był uprzednio skazany za przestępstwo umyślne z użyciem przemocy. Użyte przez ustawodawcę sformułowanie „uprzednio skazany” oznacza, że z zakresu zastosowania tej regulacji prawnej nie mógł skorzystać sprawca, wobec którego odstąpiono od wymierzenia kary. Nie miało też znaczenia, na jaką karę sprawca został uprzednio skazany, czy była ona orzeczona z warunkowym zawieszeniem jej wykonania oraz czy została choćby w części wykonana ${ }^{6}$. Zatem znaczenie miał sam fakt skazania. Umorzenie postępowania karnego w tym trybie było natomiast możliwe w wypadku, gdy sprawcy uprzednio warunkowo umorzono postępowanie karne za popełnienie jakiegokolwiek występku, zarówno umyślnego (w tym także popełnionego z użyciem przemocy), jak i nieumyślnego. Umorzenie postępowania w trybie art. 59a k.k. było dopuszczalne (co wynika z analizy tegoż przepisu ) w przypadku uprzedniego skazania sprawcy (nawet wielokrotnego skazania) za przestępstwa nieumyślne, jak również wobec sprawców działających w warunkach recydywy, którzy nie zostali dotychczas skazani za przestępstwa popełnione z użyciem przemocy, a nadto w stosunku do sprawców przestępstw umyślnych, jeżeli nie były one popełnione z użyciem przemocy ${ }^{7}$.

Uwzględnienie przez właściwy organ wniosku o umorzenie postępowania karnego na podstawie art. 59a k.k. mogło nastąpić tylko wtedy, gdy sprawca pojednał się z pokrzywdzonym, w szczególności w wyniku mediacji, i naprawił szkodę lub zadośćuczynił wyrządzonej krzywdzie.

4 A. Pilch, [w:] Nowelizacja prawa karnego 2015. Komentarz, red. W. Wróbel, Kraków 2015, s. 325.

5 Ibidem.

6 M. Budyn-Kulik, [w:] Kodeks Karny. Komentarz, red. M. Bydyn-Kulik et al., Warszawa 2015, s. 194.

7 Podobnie A. Pilch, op. cit., s. 326. 
Nie wystarczyło zatem (co wynikało z treści art. 59a § 1 k.k.) samo pojednanie się sprawcy z pokrzywdzonym ani też samo naprawienie szkody lub zadośćuczynienie za krzywdę. Musiały one wystąpić łącznie ${ }^{8}$. Ponadto pojednanie się sprawcy z pokrzywdzonym (w szczególności w wyniku mediacji) i naprawienie szkody wyrządzonej przestępstwem lub dokonanie zadośćuczynienia za krzywdę musi nastąpić w odpowiednim terminie, to jest przed rozpoczęciem przewodu sądowego pierwszej instancji, a zatem w myśl art. $385 \S 1$ k.p.k. (w wersji obowiązującej od dnia 1 lipca 2015 roku). Zgodnie zaś z treścią tegoż przepisu przewód sądowy rozpoczyna się od zwięzłego przedstawienia zarzutów oskarżenia przez oskarżyciela. Należy jednakże dodać, iż rozpoczęcie przewodu sądowego może mieć miejsce wielokrotnie, na przykład może nastąpić po odroczeniu rozprawy głównej albo też w wyniku (wskutek rozpoznania apelacji stron) przekazania sprawy do ponownego rozpoznania przez sąd pierwszej instancji ${ }^{9}$. Należy mieć także na względzie treść $§ 2$ byłego art. 59a k.k., wedle którego jeżeli czyn został popełniony na szkodę więcej niż jednego pokrzywdzonego, warunkiem zastosowania umorzenia postępowania karnego jest pojednanie się i naprawienie przez sprawcę szkody oraz zadośćuczynienia za wyrządzoną krzywdę w stosunku do wszystkich pokrzywdzonych. Ustawa nie wymagała jednak, aby w takim przypadku wniosek o umorzenie postępowania pochodził od wszystkich pokrzywdzonych. Wydaje się zatem, że taki wniosek mógł być złożony zarówno przez każdego z nich z osobna, jak również tylko przez jednego z pokrzywdzonych, przy — jak słusznie twierdzi V. Konarska-Wrzosek — jednoczesnym istnieniu dowodów, że sprawca naprawił szkodę lub zadośćuczynił wszystkim pokrzywdzonym ${ }^{10}$.

Warunkiem umorzenia postępowania karnego w trybie art. 59a k.k. - co wynika z powyższego — było złożenie wniosku przez osobę uprawnioną, takie zaś uprawnienie przyznano pokrzywdzonemu. Zgodnie zaś z art. 49 § 1 k.p.k. pokrzywdzonym jest osoba fizyczna lub prawna, której dobro prawne zostało bezpośrednio naruszone bądź zagrożone przestępstwem. Pokrzywdzonym może być także (zgodnie z art. 49 § 2 k.p.k.) instytucja państwowa lub samorządowa niemająca osobowości

8 Podobnie M. Budyn-Kulik, op. cit., s. 194.

9 Zob. także A. Pilch, op. cit., s. 329.

${ }^{10}$ V. Konarska-Wrzosek, op. cit., s. 397. 
prawnej lub inna jednostka organizacyjna, której odrębne przepisy przyznają zdolność prawną. Ponadto za pokrzywdzonego (zgodnie z art. 49 $\S 3$ k.p.k.) uważa się zakład ubezpieczeń w zakresie, w jakim pokrył szkodę wyrządzoną pokrzywdzonemu przez przestępstwo lub jest zobowiązany do jej pokrycia.

Wniosek pokrzywdzonego o umorzenie postępowania karnego mógł być (zgodnie z treścią przepisu art. 116 k.p.k.) złożony w formie pisemnej lub ustnie do protokołu. „Szczególne znaczenie — jak słusznie podniósł A. Lach — będą tu mieć wady oświadczenia woli, w szczególności złożenie oświadczenia pod groźbą lub z użyciem przemocy. Może też zaistnieć sytuacja, w której pokrzywdzony będzie działał pod wpływem błędu. Przed złożeniem wniosku pokrzywdzony powinien wszak upewnić się, że szkoda została rzeczywiście naprawiona" 11 .

Wniosek ten (co wynika z treści art. 59 § 1 k.k.) powinien był być złożony do rozpoczęcia przewodu sądowego w pierwszej instancji, przy czym należy podnieść, iż był to termin prekluzyjny, po którego upływie wniosek należało uznać za bezskuteczny ${ }^{12}$. Tworząc zaś instytucję umorzenia postępowania karnego w trybie art. 59a k.k., ustawodawca nie zawarł żadnego przepisu ograniczającego czy też wyłączającego możliwość cofnięcia wniosku przez pokrzywdzonego. „Ustawodawca tym samym pozostawił pokrzywdzonemu swobodę w zakresie dysponowania wnioskiem. W rezultacie pokrzywdzony może [mógł - B.M.] wiążąco i skutecznie cofnąć złożony przez siebie wniosek, aż do uprawomocnienia się postanowienia wydanego w przedmiocie tego wniosku"13. Możliwość zaś cofnięcia wniosku przez pokrzywdzonego daje art. $12 \S 3$ k.p.k., zgodnie z którym wniosek może być cofnięty w postępowaniu przygotowawczym za zgodą prokuratora, a w postępowaniu sądowym za zgodą sądu, do rozpoczęcia przewodu sądowego na pierwszej rozprawie głównej. Ponowne złożenie wniosku jest niedopuszczalne. Należy także podnieść, iż w art. 59a k.k. ustawodawca przewidywał wyłącznie możliwość umorzenia postępowania karnego, co oznaczało, że nie było podstaw do odmowy wszczęcia po-

\footnotetext{
11 A. Lach, op. cit., s. 143.

12 Ibidem, s. 143.

13 A. Pilch, op. cit., s. 339.
} 
stępowania karnego w trybie art. 307 k.p.k. ze względu na naprawienie szkody lub zadośćuczynienie za krzywdę wyrządzoną przestępstwem ${ }^{14}$.

Należy również stwierdzić, że umorzenie postępowania karnego na podstawie art. 59a k.k. mogło mieć miejsce (mogło nastąpić) na etapie postępowania zarówno przygotowawczego, jak i sądowego (do momentu rozpoczęcia przewodu sądowego w pierwszej instancji). Przepis art. 59a k.k. nie wskazywał jednak, na jakim etapie postępowania karnego może nastąpić umorzenie, to znaczy, czy może mieć ono miejsce już $\mathrm{w}$ fazie in rem, czy dopiero $\mathrm{w}$ fazie in personam. Moim zdaniem z uwagi na to, że ustawodawca posłużył się w art. 59a k.k. określeniem „sprawca" (odnoszącym się do realizacji znamion konkretnych typów czynów przestępczych wskazanych w tym przepisie) umorzenie postępowania karnego w trybie tegoż przepisu powinno nastąpić wyłącznie w fazie in personam $^{15}$. W toku postępowania karnego organ procesowy powinien bowiem, na podstawie zebranego w danej sprawie materiału dowodowego, mieć pewność zarówno co do sprawstwa, jak i winy określonej osoby w zakresie popełnienia przez nią przestępstw (występków) określonych w art. 59a k.k. Ta pewność dowodowa (przekonanie procesowe) skutkować będzie postawieniem danej osobie określonych zarzutów, w trybie art. 313 k.p.k. W mojej ocenie zatem umorzenie postępowania karnego na podstawie art. 59a k.k. nie mogło być możliwe na etapie fazy in rem (kiedy nie przedstawiono jeszcze zarzutów, postępowanie karne zaś toczy się jedynie w sprawie).

Z przepisu art. 59a $\S 1$ k.k. wynikała (o czym świadczy sformułowanie ,umarza się”) obligatoryjność umorzenia postępowania karnego na wniosek pokrzywdzonego (zaspokojonego pokrzywdzonego), gdy spełnione byłyby pozostałe przesłanki określone w $\S 1$ (jak i $\S 2$ ) tegoż przepisu. Jednak - jak słusznie zauważa V. Konarska-Wrzosek — ,uregulowania przepisu art. 59a $\S 3$ k.k. sprawiają, że jest to obligatoryjność względna, gdyż sąd może nie dokonać umorzenia (a nawet nie powinien), jeśli uzna, że w danym przypadku umorzenie nie da się pogodzić z ustaloną potrzebą realizacji celów kary, czy to ze względów sprawiedliwościowych czy prewencyjnych"16. A zatem negatywna przesłanka

\footnotetext{
14 Podobnie A. Lach, op. cit., s. 143.

15 Podobnie A. Pilch, op. cit., s. 324-325; zob. także A. Lach, op. cit., s. 143-144.

16 V. Konarska-Wrzosek, op. cit., s. 397.
} 
umorzenia postępowania karnego określona w art. 59a $\S 3$ k.k. ma tutaj charakter względnie obligatoryjny.

\section{III}

Z przepisu art. 59a k.k. wynikała więc możliwość umorzenia postępowania karnego w stadium zarówno przygotowawczym, jak i sądowym (ale tutaj wyłącznie do czasu rozpoczęcia przewodu sądowego w pierwszej instancji) na wniosek pokrzywdzonego. W przepisie tym jednakże (mającym bez wątpienia usprawnić proces karny i zmierzać do zredukowania liczby spraw karnych trafiających do sądu ${ }^{17}$ ) udzielono upoważnienia do zakończenia procesu karnego (postępowania karnego) organowi innemu niż sąd w kontekście konstytucyjnie gwarantowanej zasady sądowego wymiaru sprawiedliwości, określonej w art. 175 ust. 1 Konstytucji $\mathrm{RP}^{18}$. Z tego przepisu ustawy zasadniczej jednoznacznie wynika, że wymiar sprawiedliwości stanowi w polskim systemie prawnym wyłącznie domenę sądów. W obliczu zaś tejże bezwzględnej zasady konstytucyjnej usprawnienie procesu karnego poprzez odciążenie sądów od zajmowania się sprawami błahymi (prostymi) i w ten sposób zredukowanie liczy spraw karnych trafiających do sądu (zapewniające tym samym koncentrację sądów na sprawach poważniejszych o zdecydowanie cięższym wymiarze gatunkowym) nie może odbywać się za cenę jej naruszenia ${ }^{19}$. Mamy więc tutaj do czynienia z niekonstytucyjnością art. 59a k.k. Należy zatem podkreślić, że wynikające z byłego już przepisu art. $23 \mathrm{~b} \S 1$ k.p.k. W zW. z art. 59a k.k. upoważnienie urzędu prokuratorskiego do umorzenia postępowania karnego na wniosek pokrzywdzonego wskutek naprawienia szkody lub zadośćuczynienia krzywdzie przez sprawcę przestępstwa było nie do pogodzenia $\mathrm{z}$ określoną $\mathrm{w}$ art. $175 \S 1$ Konstytucji RP konstytucyjną zasadą sądowego wymiaru sprawiedliwości ${ }^{20}$. Wydaje się także, iż

17 Zob. także J. Zagrodnik, O pojęciu ,wymiar sprawiedliwości” w kontekście umorzenia postępowania przygotowawczego na wniosek pokrzywdzonego, „Iustitia” 2015, nr 2 (20), s. 78.

18 Konstytucja Rzeczypospolitej Polskiej z dnia 2 kwietnia 1997 r. (Dz.U. Nr 78, poz. 483), z mocą obowiązującą z dniem17 października $1997 \mathrm{r}$.

19 J. Zagrodnik, op. cit., s. 78-79.

20 Podobnie ibidem, s. 86-87. 
art. 59a k.k. był przepisem niekonstytucyjnym względem art. 42 ust. 3 Konstytucji, wedle którego każdego uważa się za niewinnego, dopóki jego wina nie zostanie stwierdzona prawomocnym wyrokiem sądu. Tak ukształtowana zasada domniemania niewinności (praesumptio boni viri) ma podstawowe znaczenie dla określenia procesowej pozycji oskarżonego $^{21}$. Tym samym przepis art. 59a k.k. był także sprzeczny z wyrażoną $\mathrm{w}$ art. $5 \S 1$ k.p.k. zasadą domniemania niewinności, zgodnie z którą oskarżonego uważa się za niewinnego, dopóki jego wina nie zostanie udowodniona i stwierdzona prawomocnym wyrokiem. Taka zaś sytuacja procesowa zachodzi dla oskarżonego w przypadku zarówno prawomocnego wyroku skazującego, jak i prawomocnego wyroku warunkowo umarzającego postępowanie karne. Oznacza to, że umorzenie wnioskowe jest dla sprawcy korzystniejsze od warunkowego umorzenia postępowania karnego (art. $66 \S 1$ i 2 k.k.).

Kolejna wątpliwość dotyczy charakteru prawnego tej instytucji. Analizując tę kwestię, na wstępie należy podnieść, iż umorzenie wnioskowe z art. 59a k.k. jest umorzeniem bezwarunkowym. Zatem postanowienie o umorzeniu postępowania na podstawie tego przepisu nie może być wzruszone z uwagi na czyny przestępcze popełnione po wydaniu takiego postanowienia. Przedmiotowa instytucja nie ma więc charakteru środka probacyjnego. Ponadto należy podnieść, że zastosowanie instytucji przewidzianej w art. 59a k.k. byłoby możliwe tylko wtedy, gdy nie zaistnieją negatywne przesłanki procesowe z art. 17 § 1 k.p.k., skutkujące także bezwarunkowym umorzeniem postępowania karnego. Umorzenie wnioskowe zatem miałoby miejsce wtedy, gdy proces karny byłby dopuszczalny ze względów faktycznych i prawnych. Podstawą umorzenia przy spełnieniu przesłanek umorzenia wnioskowego będzie zatem art. 59a k.k., a nie art. $17 \S 1$ k.p.k. ${ }^{22}$ Należy jednak podkreślić, iż umorzenie wnioskowe nie mogło być stosowane jako swoiste remedium na braki dowodowe. Dlatego też w mojej ocenie podjęcie decyzji o umorzeniu postępowania na zasadzie art. 59a k.k. byłoby możliwe dopiero po wyjaśnieniu okoliczności danej sprawy karnej (wszystkich jej okoliczności)

21 P. Wiliński, Proces karny w świetle Konstytucji, Warszawa 2011, s. 167.

22 A. Lach, op. cit., s. 138. 
oraz ustaleniu sprawstwa (i winy) osoby, która dopuściła się czynu przestępczego, określonego w art. 59a § 1 k.k.

Analizowany przepis można także określić jako „swoistą postać niekaralności sprawcy”23 oraz „finansowy sposób na uniknięcie odpowiedzialności karnej” przez sprawcę przestępstwa. Wydaje się bowiem, iż z przedmiotowej instytucji przede wszystkim korzystaliby bardziej majętni przestępcy, którzy chcieliby w ten sposób uniknąć odpowiedzialności karnej za popełnione czyny przestępcze.

Podsumowując poczynione rozważania, należy stwierdzić, iż były już przepis art. 59a k.k. stanowił bez wątpienia odstępstwo od zasady legalizmu, stanowiąc jednocześnie — jak słusznie zauważa A. Lach przejaw oportunizmu procesowego. $Z$ tego też względu dziwić musi jego umiejscowienie w k.k., a nie w k.p.k. ${ }^{24}$

Moim zdaniem ideę wprowadzenia tejże instytucji (umorzenia wnioskowego) do prawnokarnego obrotu prawnego należy ocenić raczej negatywnie, tym bardziej że w prawie karnym funkcjonują już przecież inne instytucje ,o charakterze umorzeniowym”, a mianowicie przewidziane w art. 11 k.p.k. umorzenie absorpcyjne oraz w art. 66 k.k. warunkowe umorzenie postępowania karnego.

Przede wszystkim jednak na negatywną ocenę rzutuje to, iż art. 59a k.k. był przepisem niekonstytucyjnym w stosunku do art. 175 ust. 1 i art. 42 ust. 3 Konstytucji oraz to, że instytucja ta raczej preferowałaby bogatych sprawców przestępstw, stosując tym samym swoisty (finansowy) sposób na unikniecie odpowiedzialności karnej. Można zatem stwierdzić iż umorzenie wnioskowe było chybionym rozwiązaniem legislacyjnym ustawodawcy. Dlatego też dobrze się stało, że przepis art. 59a k.k. został uchylony ${ }^{25}$.

23 M. Kurowski, Umorzenie postępowania karnego na podstawie art. 59 a k.k., [w:] Polski proces karny i materialne prawo karne w świetle nowelizacji z 2013 roku. Ksiega jubileuszowa dedykowana Profesorowi Januszowi Tylmanowi z okazji Jego 90. urodzin, red. T. Grzegorczyk, Warszawa 2014, s. 440, 450.

24 A. Lach, op. cit., s. 147.

25 Zob. przypis 1. 


\section{Article 59a of the Criminal Code - a success or a failure of the legislator}

Summary

The article focuses on the now repealed ${ }^{26}$ measure of discontinuance of criminal proceedings under Article 59a of the Criminal Code following a request of the injured arty in case of damage redress (or compensation for the injury caused by the crime). In the article the author criticises the measure in question on many levels, also analysing the grounds for and the mode of discontinuance.

Keywords: compensatory discontinuance, criminal proceedings, speed and efficiency of proceedings.

${ }^{26}$ The provision of Article 59a of the Criminal Code (in force as of 1 July 2015) was repealed by the Act of 11 March 2016 (Journal of Laws 2016, item 437), which entered into force on 15 April 2016. 